\title{
A New Market for an Old Food: the U.S. Demand for Olive Oil
}

\author{
Bo Xiong , Daniel Sumner`, William Matthews*
}

\begin{abstract}
While U.S. consumption of olive oil has tripled over the past two decades, nearly all olive oil continues to be imported. Estimation of a demand system using monthly import data reveals that the income elasticity for virgin oils sourced from EU is above one, but demand for non-virgin oils is income-inelastic. The demand for olive oil as a single product is price-inelastic. Differentiated by product characteristic and origin, olive oils are highly substitutable with each other but not with other vegetable oils. News about the health and culinary benefits of olive oil and the spread of Mediterranean diet contribute significantly to the rising demand.
\end{abstract}

Keywords: olive oil, food demand, Mediterranean diet, health, dietary trend

JEL classification: Q11, Q17

\footnotetext{
- Bo Xiong, boxiong@ucdavis.edu, is a postdoctoral researcher at the Agricultural Issues Center, University of California. One Shields Avenue, Davis, CA. 95616, USA. Tel: (530)752-5355. Fax: (530)752-5614. The authors thank Julian Alston, Samir Mili, Sebastien Pouliot, and Luca Salvatici for their comments. The authors also thank Georgi Gabrielyan and Jonathan Barker for assistance. The authors appreciate the exchanges of ideas with the U.S. International Trade Commission. The research was partially funded by the California Department of Food and Agriculture, Specialty Crops Grant Program.

^Daniel Sumner, dasumner@ucdavis.edu, is the director of the Agricultural Issues Center, University of California and the Frank Buck Jr. Professor in the Department of Agricultural and Resource Economics at UC Davis and a member of the Gianini Foundation. One Shields Avenue, Davis, CA. 95616, USA.

*William Matthews, wamatthews@ucdavis.edu, is a project scientist at the Agricultural Issues Center, University of California. One Shields Avenue, Davis, CA. 95616, USA.
} 


\section{Introduction}

Diets and food demands are changing globally. Consumers are paying increasing attention to health and flavors and broadening their consumption basket to include food items that were once considered exotic. ${ }^{1}$ In recognition of food trends, agricultural economists have expanded the focus of food demand research to understand the impacts of diet and health knowledge on consumption patterns (e.g., Kinnucan et al., 1997; Kaabia, Angulo, and Gil, 2001; Martinez, 2013).

Recently, olive oil is making news and raising important economic and policy issues. In September 2012, The Economist discussed the spread of the appetite for olive oil beyond the Mediterranean region (The Economist, 2012). Based on the new clinical evidence published in the New England Journal of Medicine (Estruch et al., 2013), the New York Times in February 2013 highlighted the effectiveness of olive oil in warding off heart attack and stroke (Kolata, 2013). In the policy arena, the United States International Trade Commission (USITC) held a public hearing in December 2012 to assess the U.S. competitiveness in olive oil in the context of global market trends and policies, as part of a larger project requested by the U.S. Congress (USITC, 2012). At the USITC hearing, U.S. olive oil industry representatives expressed concerns about European olive oil policies as well as quality standards and compliance issues. In response, the European olive industry asked the European Commission to be ready to act on the potential threats of the U.S. trade barriers (Butler, 2012).

Global production and trade of olive oil is large and significant, especially in the Mediterranean region including North Africa the Middle East. Global production value averages almost \$11 billion with about $\$ 1.8$ billion in production value in the Middle East and North

\footnotetext{
${ }^{1}$ See for example the "What We Eat in America” national food survey conducted by the U.S. Department of Health and Human Services and the U.S. Department of Agriculture.
} 
African and most of the rest in the European Union. Exports from the Middle East and North Africa are valued at almost $\$ 1$ billion while EU exports of olive oil is worth about $\$ 2$ billion based on International Olive Commission data. Olive oil production and exports have been growing rapidly from the Middle East and North Africa and these regions also have been shifting exports from non-virgin to virgin oil export.

Despite the rising importance of olive oil consumption in markets outside of the Mediterranean region, we find no econometric studies of olive oil demand in those markets. We fill this gap by providing the first estimates that characterize the demand for olive oil in the United States, a rapidly expanding market and the largest import destination for olive oil (excluding intra-EU trade).

In this article we estimate the U.S. demand for olive oil products and investigate several demand drivers, such as relative prices, personal income, and dietary information. We highlight rising consumer awareness of the health benefits of olive oil and the spread of Mediterranean diet in the United States. We use U.S. monthly imports of olive oil over the period January 1990 through December 2012 to estimate a demand system for olive oils. We find that the income elasticity for virgin oils sourced from EU is above one, but demand for non-virgin oils is incomeinelastic. Moreover, the demand for olive oil as a single product is price-inelastic. Differentiated by product characteristic and origin, olive oils are highly substitutable with each other but not with other vegetable oils. News about the health and culinary benefits of olive oil and the spread of Mediterranean diet contribute significantly to the rising demand in the United States.

\subsection{The world and the U.S. markets}

Global production of olive oil has more than doubled from about 1.5 million metric tons in 1990 to more than 3 million tons in 2012 (International Olive Council). Major producing 
regions that surround the Mediterranean Sea produce about 95 percent and consume about twothirds of the world's olive oil. Meanwhile, new markets have been growing quickly. In the United States more than 300,000 tons of olive oil were sold in 2012, tripling the quantity sold in 1990. Nevertheless, olive oil remains a tiny share in U.S. consumption of all vegetable oils, which was more than 12 million tons in $2012 .^{2}$ While consumption has grown, the U.S. production of olive oil has remained low. The U.S. olive industry only supplied 4,000 tons of olive oil in 2012, about 1.3 percent of olive oil marketed in the United States.

The rising demand for olive oil in the United States has been met by imports from Southern Europe, Northern Africa, and the Middle East. More than half of the U.S. olive oil imports are shipped from Italy. ${ }^{3}$ Although the market share of shipment from Italy has declined in recent years, U.S. olive oil imports from Italy were still worth more than $\$ 500$ million in 2012, while U.S. imports of olive oils from Spain were worth about \$200 million. Other major suppliers of olive oils to the United States include Greece, Turkey, Tunisia, and Morocco.

\subsection{Olive oil as a specialty vegetable oil}

Compared with ordinary cooking oils (e.g., soybean oil, corn oil, palm oil, and peanut oil), olive oil features unique health benefits and is a major part of the Mediterranean diet. Research has documented that olive oil is effective in lowering levels of blood cholesterol, reducing the risk of breast cancer, and helping calcium absorption (Owen et al., 2000; Tuck and Hayball, 2002; Sofi et al., 2008). More recently, Estruch et al. (2013) further documented that olive oil is a primary ingredient in the Mediterranean diet that contributes to long life and good health.

\footnotetext{
${ }^{2}$ See Table 06 under the menu "Oilseeds" of the PSD online, USDA. http://www.fas.usda.gov/psdonline/.

${ }^{3}$ From the custom data one can identify where the olive oil is shipped from, rather than where the olive oils are actually produced. For example, olive oils departing from the Italian ports might be extracted from olives grown in other countries.
} 
The industry standard for quality of olive oil is closely related to the method of extraction. According to the International Olive Council (IOC) standards, olive oil produced without chemical treatments and reaching acidity of less than 2 percent is qualified as "virgin olive oil” (International Olive Council, 2011). Virgin olive oil is sold at premium prices. Similar quality designations are used in the United States, but the retail grades and quality standards developed by the International Olive Council are not binding in the United States. In 2010 the U.S. Department of Agriculture launched a quality monitoring program for olive oils marketed in the United States (USDA-AMS), but the program is voluntary. The USITC public hearing in December 2012 engaged stake holders in the domestic industry in part to consider possible U.S. quality control measures and other public policies for the olive oil market. In that context some have raised the potential of a federal marketing order to implement mandatory grading of all olive oil marketed in the United States.

The rest of the article is organized as follows. We describe the data and highlight the stylized facts in Section 2. After outlining the econometric specification in Section 3, we present the empirical results and discuss the implications in Section 4. In the last section we offer conclusions and directions for future research.

\section{Data and market trends}

\subsection{The import data}

Since all but a tiny fraction of olive oil consumed in the United States is imported and the United States does not re-export olive oil, we use the U.S. custom data to measure consumption quantities. Specifically, we use monthly olive oil import series for the period January 1990 through December 2012. ${ }^{4}$ We compute the import prices as import values divided by import

\footnotetext{
${ }^{4}$ The 10-digit product codes for olive oil imports in the USITC database are: 1509102000, 1509104000, 1509902000, and 1509904000. Note that olive oils blended with other types of vegetable oils are not considered.
} 
quantities. We exclude tariffs from our analysis because U.S. duty rates for olive oils are low and have not changed over the past two decades. ${ }^{5}$ According to the product classifications at the 10 digit level, U.S. olive oil imports can be differentiated along three characteristics. First, based on the method of extraction, olive oils are either qualified as virgin or not. ${ }^{6}$ Second, olive oil imports arrive at U.S. ports either in small containers (less than 18 kilograms) or in large bulk containers (larger than 18 kilograms). Third, olive oil imports can be differentiated by exporting country. Next we review the three characteristics and propose a method of product aggregation that allows a feasible empirical specification while retaining the consistency with consumer theory.

\subsection{The classification of products}

We discuss the classification of olive oils by characteristics (virgin versus non-virgin), container size (less or larger than 18 kilograms), and the country of export.

Figure 1 shows the relative prices among different types of olive oils and between olive oil and other major vegetable oils. Virgin olive oils are sold at prices higher than non-virgin olive oils in the United States. In 2012 the price of virgin olive oil was about \$3.30 per kilogram, while the price of non-virgin olive oil was about $\$ 2.60$. Furthermore, virgin olive oils are more likely to be sold in retail stores while non-virgin olive oils are primarily used in food service or food processing. Therefore, our demand system differentiates olive oils by virgin and non-virgin.

\footnotetext{
${ }^{5}$ The general import tariff rates applied to olive oil in small and large containers are 5 and 3.4 cents per kilogram. Preferential treatment was granted to Jordan in 2002, Chile in 2004, Morocco in 2006, and Peru in 2010. On an Ad Valorem basis, the tariff rates are less than one percent. http://www.usitc.gov/tata/hts/index.htm

${ }^{6}$ Although the label "extra virgin" is often used in retail outlets, there is no "extra virgin" designation is custom data, either under the 10-digit Expert code or under the 8-digit Harmonized System code. Therefore, the "extra virgin" designation is subsumed into the "virgin" designation in our empirical specification.
} 
Figure 1. Prices of selected vegetable oils, \$/kg, 1990-2012

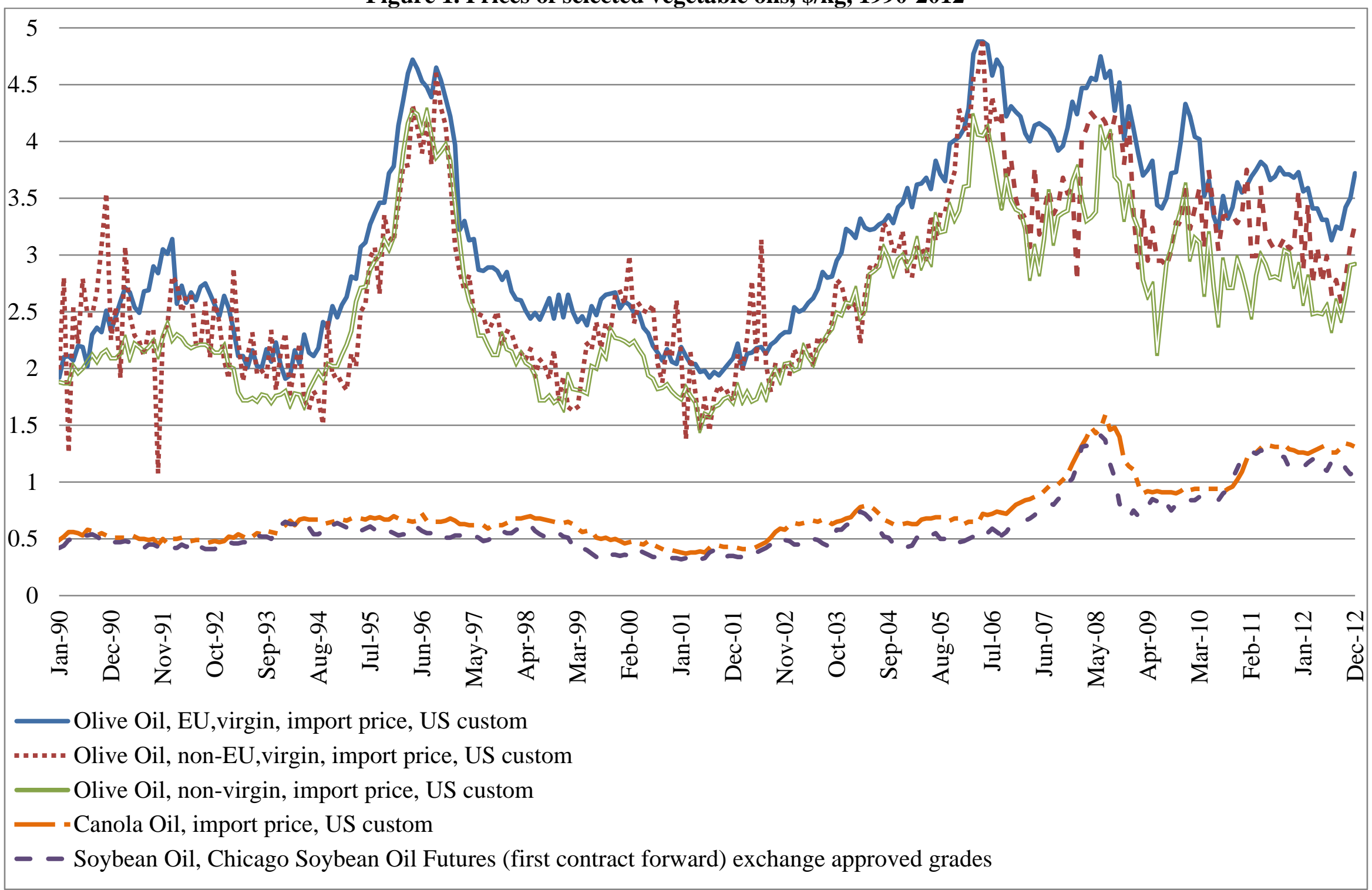

Sources: US custom data are from USITC and other prices are from IMF primary commodity prices. 
The share of olive oils shipped in containers larger than 18 kilograms increased from 20 percent in 1990 to about 30 percent in 2012. In particular, a higher proportion of imports are shipped in large containers for non-virgin olive oils and olive oils shipped from non-EU countries. Industry sources suggest that more bulk imports are blended and bottled within the United States over the years. Therefore, the information about the container size at the ports does not necessarily reflect the channels through which the olive oil products are finally distributed. To conserve degrees of freedom in our econometric specification, we do not differentiate olive oils by the size of containers in which they reach the U.S. ports.

Finally, the export origin is potentially important for olive oil. We first define two broad sourcing regions for U.S. olive oil imports: EU and non-EU. We hypothesize that consumers associate EU olive oils with higher quality or better reputation. Menapace et al. (2011) finds in a willingness-to-pay study that Canadian consumers value Italian extra virgin olive oils significantly more than other EU extra virgin oils. To consider the potential origin premium attached to Italian olive oils, we also use Italian and non-Italian as our alternative method to group countries of export. We do not differentiate non-virgin olive oils by source because the price difference is negligible. In summary, we use two product classification schemes for the U.S. olive oil imports each of which has three olive oil types. These two classification schemes are: (a) virgin oils imported from EU countries, virgin oils imported from elsewhere, and nonvirgin oils; (b) virgin oils imported from Italy, virgin oils imported from other countries, and non-virgin oils.

\subsection{The demand shifters}

Olive oil is a traditional food in the Mediterranean, but has not been widely used in the United States and while growing rapidly still comprises a small share of vegetable oil used in the 
United States. We hypothesize that the rising consumer awareness of the health benefits of olive oil, and Americans' growing appetite for the Mediterranean diet in general, likely contributes to the growth of U.S. olive oil market. To incorporate these plausible demand shifters, we use the number of articles published in U.S. newspapers, newswires, blogs, broadcast transcripts, business journals, and periodicals that report the healthiness or culinary benefits of olive oil. Specifically, we search within the News Bank database (http://www.newsbank.com/) for articles containing the key words "health" and "olive oil”, or "cholesterol” and "olive oil”, or "heart" and "olive oil" in their lead paragraphs. ${ }^{7}$ We also retrieve news articles on the trendiness of olive oil by identifying articles with the key words "taste" and "olive oil”, or "recipe" and "olive oil” in the lead paragraphs. Finally, we sum the two stocks of articles after removing any double counting in the two sets of searches.

News articles about the healthiness or culinary benefits of olive oil can affect the consumption through two closely related but distinct channels. First, the accumulated knowledge of the benefits of olive oil changes U.S. consumers' information set. That is, we measure the long-run impacts of the relevant information on consumers' demand for olive oil. Second, recent publications serve as reminders of the stock of information about which consumers may be aware. An additional bit of information may have limited duration impacts on consumer's demand as well as an effect through the addition to the stock of knowledge. To capture both the knowledge and the limited duration reminder effects, we create two variables from the abovedefined news articles. First, we count the total number of articles, either addressing the

\footnotetext{
${ }^{7}$ Brown and Schrader (1990) first proposed using articles published in the biomedical literature to construct health information index to explain the consumption of shell eggs. We go beyond academic databases in order to focus on the dissemination rather than the discovery of scientific knowledge.
} 
healthiness or the culinary benefits of olive oil, published one year ago or earlier. Second, we count the total number of news articles published within the past twelve months. ${ }^{8}$

In addition, to control for Americans' changing appetite for Mediterranean food in general, we use U.S. monthly import of Italian-style cheese (e.g., Reggiano, Parmesan, Provolone, Provoletti, Sbrinz, and Goya). Compared with articles on olive oil, the import of Italian-style cheese reflects a broader change in American dietary habits and partially controls for the substitutability or complementarity of olive oil with other Mediterranean foods.

Next we address the substitution between olive oil and other vegetable oils. Two facts are evident from Figure 1. First, olive oil is far more expensive than canola or soybean oil. ${ }^{9}$ Second, the prices of canola and soybean oils are highly correlated, but the prices of olive oils exhibit unique patterns. ${ }^{10}$ Statistically, the correlation of olive oil price is about 0.21 with soybean oil price, and 0.32 with canola oil price. ${ }^{11}$ More than twenty years ago Pierani and Rizzi (1991) documented the low substitutability of olive oil with other vegetable oils in Italy at that time. They found that the cross-price elasticity of demand for olive oil in Italy was less than 0.08. Similarly, Mili (1996) found that sunflower oil, the major alternative vegetable oil in Spain, substitutes for non-virgin but not virgin olive oils. We include the U.S. monthly import price of canola oil to account for the potential substitution between olive oil and other vegetable oils. Finally, we include data on U.S. personal income, U.S. population, and the U.S. monthly

\footnotetext{
${ }^{8}$ We also consider 6-month and 18-month period as the alternative ways to differentiate the knowledge and reminder effects of news articles. Both effects are robust to the alternative specifications.

${ }^{9}$ The U.S. monthly import price of canola oil is computed as the import value of rapeseed oil divided by the import quantity of rapeseed oil. Since most of the imported rapeseed oils are canola oils sourced from Canada, we can use the unit value of rapeseed oil to represent the price of canola oil.

${ }^{10}$ The prices of palm oil and sunflower oil also move along with the price of soybean or canola oil. See the IMF commodity prices for details.

${ }^{11}$ In computing the correlations, prices are deflated by CPIs. Olive oils are sometimes blended with canola oils in food service use. For example, the Corning Olive Oil company of California offers a special blend of $80 \%$ canola oil and $20 \%$ olive oil for pan frying and deep frying at high temperatures.

http://www.corningoliveoil.com/index.php?main_page=indexandcPath=16
} 
Consumer Price Index for foods. Appendix A compiles information on all data series and sources.

\subsection{Summary statistics}

We present in Table 1 summary statistics of the data. To illustrate the market trends, we also provide separate summary statistics over the first five years, 1990-1994, and the last five years, 2008-2012. As shown in Table 1, the rising quantity of olive oil in the United States is largely confined to the increased consumption of virgin oils. The monthly per-capita consumption of virgin olive oil from EU sources has grown from 10 grams in early 1990s to nearly 40 grams in recent years. Moreover, the market share of virgin oils imported from non-EU countries has increased from about zero to more than 10 percent. In contrast, the U.S. import of non-virgin olive oil has been stagnant.

While there is no clear trend in the prices of olive oils over the past two decades (as illustrated in Figure 1), the ranking of prices of three types of olive oils has been consistent over time. The import price of virgin oil sourced from EU is higher than virgin oil sourced from elsewhere, and non-virgin oil is sold at an even lower price.

Our count of articles on the healthiness or culinary benefits of olive oil begins in 1980 but the publications before 1990 were few. The number of articles rose to about 50 per month in 1990s. Numbers of articles published declined in the early 2000s, but climbed again after 2004 . In recent years, the number of articles varies substantially around an average of 50 per month. 
Table 1. Summary statistics for U.S. olive oil demand

\begin{tabular}{|c|c|c|c|}
\hline Variable & $\begin{array}{c}\text { Mean } \\
\text { full sample }\end{array}$ & $\begin{array}{c}\text { Mean } \\
\text { Jan/90-Dec/94 }\end{array}$ & $\begin{array}{c}\text { Mean } \\
\text { Jan/08-Dec/12 }\end{array}$ \\
\hline Per-capita consumption of EU/Virgin, gram & $\begin{array}{c}25.31 \\
(12.38)\end{array}$ & $\begin{array}{l}10.00 \\
(2.88)\end{array}$ & $\begin{array}{l}39.28 \\
(5.80)\end{array}$ \\
\hline Per-capita consumption of Non-EU/Virgin, gram & $\begin{array}{c}4.77 \\
(4.54)\end{array}$ & $\begin{array}{c}1.11 \\
(1.55)\end{array}$ & $\begin{array}{l}10.05 \\
(4.06)\end{array}$ \\
\hline Per-capita consumption of Italian/Virgin, gram & $\begin{array}{l}17.94 \\
(8.71)\end{array}$ & $\begin{array}{c}6.78 \\
(2.24)\end{array}$ & $\begin{array}{l}26.70 \\
(3.94)\end{array}$ \\
\hline $\begin{array}{l}\text { Per-capita consumption of Non-Italian/Virgin, } \\
\text { gram }\end{array}$ & $\begin{array}{l}12.13 \\
(8.30)\end{array}$ & $\begin{array}{c}4.33 \\
(2.52)\end{array}$ & $\begin{array}{l}22.63 \\
(6.82)\end{array}$ \\
\hline Per-capita consumption of Non-Virgin, gram & $\begin{array}{l}24.67 \\
(5.47)\end{array}$ & $\begin{array}{l}23.68 \\
(4.76)\end{array}$ & $\begin{array}{l}22.88 \\
(5.35)\end{array}$ \\
\hline Price of EU/Virgin, \$/kg & $\begin{array}{c}3.11 \\
(0.82)\end{array}$ & $\begin{array}{c}2.39 \\
(0.31)\end{array}$ & $\begin{array}{c}3.79 \\
(0.41)\end{array}$ \\
\hline Price of Non-EU/Virgin, \$/kg & $\begin{array}{c}2.77 \\
(0.76)\end{array}$ & $\begin{array}{c}2.25 \\
(0.44)\end{array}$ & $\begin{array}{c}3.33 \\
(0.46)\end{array}$ \\
\hline Price of Italian/Virgin, $\$ / \mathrm{kg}$ & $\begin{array}{l}3.16 \\
(0.85)\end{array}$ & $\begin{array}{l}2.43 \\
(0.36)\end{array}$ & $\begin{array}{c}3.93 \\
(0.40)\end{array}$ \\
\hline Price of Non-Italian/Virgin, $\$ / \mathrm{kg}$ & $\begin{array}{c}2.91 \\
(0.76)\end{array}$ & $\begin{array}{c}2.27 \\
(0.26)\end{array}$ & $\begin{array}{c}3.43 \\
(0.44)\end{array}$ \\
\hline Price of Non-Virgin, \$/kg & $\begin{array}{l}2.56 \\
(0.70)\end{array}$ & $\begin{array}{c}2.01 \\
(0.20)\end{array}$ & $\begin{array}{c}2.98 \\
(0.44)\end{array}$ \\
\hline Per-capita personal income, $\$ 1000$ & $\begin{array}{l}30.77 \\
(7.56)\end{array}$ & $\begin{array}{l}20.75 \\
(1.11)\end{array}$ & $\begin{array}{l}40.69 \\
(1.46)\end{array}$ \\
\hline Price of canola oil, $\$ / \mathrm{kg}$ & $\begin{array}{c}0.73 \\
(0.28)\end{array}$ & $\begin{array}{c}0.54 \\
(0.06)\end{array}$ & $\begin{array}{c}1.17 \\
(0.20)\end{array}$ \\
\hline \# of accumulated articles, up to 12 months ago & $\begin{array}{c}4047 \\
(3281)\end{array}$ & $\begin{array}{c}764 \\
(307)\end{array}$ & $\begin{array}{l}9441 \\
(830)\end{array}$ \\
\hline \# of articles, in the past 12 months & $\begin{array}{c}455 \\
(178)\end{array}$ & $\begin{array}{l}220 \\
(30)\end{array}$ & $\begin{array}{c}513 \\
(162)\end{array}$ \\
\hline Per-capita import of Italian cheese, gram & $\begin{array}{c}2.19 \\
(1.15)\end{array}$ & $\begin{array}{c}1.19 \\
(0.73)\end{array}$ & $\begin{array}{c}3.12 \\
(0.79)\end{array}$ \\
\hline CPI, June $2000=1$ & $\begin{array}{c}1.04 \\
(0.17)\end{array}$ & $\begin{array}{c}0.81 \\
(0.04)\end{array}$ & $\begin{array}{c}1.28 \\
(0.04)\end{array}$ \\
\hline
\end{tabular}

Note: Standard deviations are in parentheses. 


\section{The econometric specification}

\subsection{The choice of demand system}

With the assumption that the total expenditure on the commodities of interest is separable from the overall budget, complete demand systems can be derived to characterize consumption patterns in a way consistent with consumer theory (Deaton and Muellbauer, 1980). ${ }^{12}$ Previous studies on the U.S. consumption of vegetable oils treated "oils and fats" as a group and focused on major vegetable oils such as corn, cottonseed, and soybean oils (e.g., Chern, Loehman, and Yen, 1995). The omission of olive oil in earlier research was due to the tiny share of olive oil, which accounted for about 2.5 percent of all vegetable oils in 2012 (USDA-FAS, oilseeds reports). Rather than focusing on all vegetable oils, we treat all olive oils as the relevant group and hence treat Americans' total expenditure on olive oils as separable from other purchases. With this assumption, we formulate a conditional demand system that characterizes the quantities demanded for individual types of olive oils and investigate the substitution patterns within the varieties of olive oil and between olive oil and canola oil.

A major caveat of separating the expenditure on olive oil from the overall budget is that the expenditure on olive oil is simultaneously determined with quantity demanded for all types of olive oils. Two remedies exist in the literature. The first applies the instrumental variable approach to the demand system (e.g., LaFrance, 1991). This approach takes advantage of extra variables that affect the consumption patterns only through influencing the total expenditure on the commodity group. The second approach models the demand equation and the expenditure equation simultaneously (e.g., Dhar, Chavas, and Gould, 2003; Hovhannisyan and Gould, 2011). We choose to estimate simultaneous equations because it sheds light on the determinants of the

\footnotetext{
${ }^{12}$ See Okrent and Alston (2011) for a recent survey on the developments in the literature of food demand.
} 
total expenditure on olive oils and delivers income elasticities using estimates from both equations.

Since the separability assumption in the complete demand system may not hold, to check robustness of the estimates, we also fit an incomplete demand system in which the quantity demanded for olive oil is explained by prices of olive oils, personal income, and other shifters.

We discuss the associated results in section 4.2.

\subsection{The AIDS model with endogenous variables}

We use the Almost Ideal Demand System (AIDS) as the econometric specification for the olive oil demand. Specifically, the U.S. demand for olive oils is characterized as:

(1) $s_{i t}=\alpha_{i}+\beta_{i} \ln \left(m_{t}\right)-\beta_{i} \ln P_{t}+\sum_{j} \gamma_{i j} \ln \left(p_{j t}\right)+\theta_{i}$ trend $_{t}+\sum_{n=1}^{12} \chi_{i n} T_{n}+\mu_{i t}$,

$$
\ln \left(m_{t}\right)=\delta+\phi \ln P_{t}+\varphi \ln \left(y_{t}\right)+\eta \ln \left(p_{c t}\right)+\lambda \ln \left(\text { cpi }_{t}\right)+\omega \ln \left(\text { cheese }_{t}\right)
$$

$$
+\tau \ln \left(\operatorname{Kart}_{t}\right)+\rho \ln \left(\operatorname{Rart}_{t}\right)+v_{t} \text {, }
$$

where $i, j$ are the product indices for the three types of olive oils, $t$ denotes period, i.e., $t \in\{1,2, \ldots, 276\}$. The dependent variable $s_{i t}$ in (1) is the expenditure share of olive oil $i$. Variable $m_{t}$ is U.S. total expenditure on olive oil; $p_{j t}$ is the price of olive oil $j ; \ln P_{t}$ is the AIDS price index, which we approximate using the corrected Stone price index (Moschini, 1995). Specifically, $\ln P_{t} \approx \sum_{j} w_{j 0} \ln p_{j t}$, where $w_{j 0}$ is the expenditure share of olive oil $j$ over the period January 2010 through December 2012. ${ }^{13}$ Other shifters in (1) include a linear time trend and monthly dummy variables to control for the seasonal variations in consumptions. ${ }^{14}$ The usual idiosyncratic error term is denoted with $\mu_{i t}$.

\footnotetext{
${ }^{13}$ We evaluate the corrected Stone price index at the recent expenditure shares to reflect the current market.

14 The dummy variable for January is dropped in all estimations due to the presence of intercepts.
} 
Equation (2) deals with the endogeneity of the expenditure variable. ${ }^{15}$ Intuitively, we explain U.S. total expenditure on olive oil using the corrected Stone price index, $\ln P_{t}$, U.S. percapita personal income, $y_{t}$, the price of canola oil, $p_{c t}$, the monthly CPI, $c p i_{t}$, U.S. per-capita import of Italian-style cheese, and the knowledge effect, $\operatorname{Kart}_{t}$, and the reminder effect, Rart $_{t}$, of news articles on the healthiness or trendiness of olive oil. ${ }^{16}$

\subsection{Estimation procedure and caveats}

To complete the demand system (1)-(2), we adopt the following parameter restrictions:

(3a) $\gamma_{i j}=\gamma_{j i}$ (symmetry),

(3b) $\sum_{j} \gamma_{i j}=0$ (homogeneity within the group of olive oils), ${ }^{17}$

(3c) $\sum_{i} \alpha_{i}=1, \sum_{i} \beta_{i}=0, \sum_{i} \chi_{\text {in }}=0$, and $\sum_{i} \theta_{i}=0$ (shares adding up to one),

(3d) $\phi+\varphi+\eta+\lambda=1$ (homogeneity outside of the group of olive oils).

We conduct two validation exercises before estimation. First, we implement the modified Dickey-Fuller tests, as proposed by Elliott, Rothenberg, and Stock (1996), for the expenditure shares in (1) and the expenditure variable in logarithmical scale in (2). We find that none of the dependent variables contains unit roots. ${ }^{18}$ Therefore, the demand system can be estimated in its original form rather than in the differenced form. Second, we check the serial correlation of expenditure shares and the total expenditure on olive oils using the Durbin-Watson test. We fail

\footnotetext{
15 The specification in (2) resembles the expenditure equation used by Thompson (2004).

${ }^{16}$ The identification of the separate effects of healthiness and trendiness of olive oil is not feasible because the two series are highly correlated.

${ }^{17}$ Note that (3a) and (3b) imply that price coefficients in each share equation sum up to zero.

${ }^{18}$ See Appendix B for the results of the unit-root tests.
} 
to reject the null hypothesis that there is no first-order serial correlation at the usual confidence level. $^{19}$

Finally, we examine the possible endogeneity of prices in the demand system. The U.S. olive oil prices might be endogenous to the U.S. olive oil import quantities for two reasons. First, the use of unit values as measurements of prices may introduce a mechanical negative correlation between the price and quantity series in the presence of measurement error. We consider the potential measurement error to be small in magnitude on two grounds. First, rounding error is negligible in the U.S. custom data because values are recorded up to the last digit of dollars and quantities are down to kilograms. Second, random reporting errors tend to cancel out because the value and quantity data that are used to compute the price series are the summation of more than a dozen U.S. ports that actively import olive oils every month.

Another potential source of endogeneity is the effect of the U.S. consumption and the world price of olive oil. However, such feedback effects are limited because the U.S. market accounts for less than 10 percent of the world consumption of olive oil (see Section 1.1). To further check the exogeneity of the U.S. import prices, we conduct the Hausman-Durbin-Wu test for the import prices of olive oils, using annual dummy variables based on marketing years and a linear time trend as the instrumental variables. The test results fail to reject the hypothesis that U.S. is a price-taker in the market for virgin olive oil at the five percent confidence level, and in the market for non-virgin olive oil at the one percent confidence level. ${ }^{20}$

\section{Results and discussions}

\subsection{The benchmark}

\footnotetext{
${ }^{19}$ See Appendix B for the results of the serial correlation tests.

${ }^{20}$ See Appendix C for the Hausman-Durbin-Wu tests based on reduced-form demand functions.
} 
We estimate the demand system (1)-(3) using 3SLS. Specifically, we report, in Table 2, four sets of regressions: with EU virgin oil or Italian virgin oil separated (in the two panels of Table 2), with or without addressing the potential endogeneity of U.S. total expenditure on olive oils (with italics for estimates without accounting for potential endogeneity). We present the elasticities of demand in Table $2 .{ }^{21}$ To make results directly relevant to the current market, we evaluate all elasticities at the market shares over the period January 2010 to December 2012.

\footnotetext{
${ }^{21}$ The estimated coefficients are presented in Appendix D.
} 
Table 2. Price elasticities of U.S. demand for olive oils

\begin{tabular}{|c|c|c|c|}
\hline \multirow[b]{2}{*}{ Demand for olive oil, of type } & \multicolumn{3}{|c|}{ Product classification I } \\
\hline & EU/Virgin & Non-EU/Virgin & Non-Virgin \\
\hline Expenditure share & $60 \%$ & $13 \%$ & $27 \%$ \\
\hline \multirow[t]{2}{*}{ Price of EU/Virgin } & $-0.436(0.063)$ & $0.997(0.145)$ & $0.498(0.132)$ \\
\hline & $-0.415(0.061)$ & $0.902(0.134)$ & $0.496(0.130)$ \\
\hline \multirow[t]{2}{*}{ Price of Non-EU/Virgin } & $0.212(0.031)$ & $-1.360(0.132)$ & $0.172(0.069)$ \\
\hline & $0.192(0.029)$ & $-1.285(0.123)$ & $0.181(0.067)$ \\
\hline \multirow[t]{2}{*}{ Price of Non-Virgin } & $0.224(0.059)$ & $0.363(0.146)$ & $-0.670(0.152)$ \\
\hline & $0.223(0.058)$ & $0.383(0.142)$ & $-0.677(0.150)$ \\
\hline \multirow[t]{3}{*}{ Expenditure } & $1.329(0.060)$ & $0.119(0.216)$ & $0.685(0.115)$ \\
\hline & $1.095(0.027)$ & $0.904(0.099)$ & $0.834(0.059)$ \\
\hline & \multicolumn{3}{|c|}{ Product classification II } \\
\hline Demand for olive oil, of type & Italy/Virgin & Non-Italy/Virgin & Non-Virgin \\
\hline Expenditure share & $42 \%$ & $31 \%$ & $27 \%$ \\
\hline \multirow[t]{2}{*}{ Price of Italy/Virgin } & $-0.820(0.097)$ & $0.744(0.098)$ & $0.414(0.120)$ \\
\hline & $-0.887(0.092)$ & $0.822(0.092)$ & $0.427(0.117)$ \\
\hline \multirow[t]{2}{*}{ Price of Non-Italy/Virgin } & $0.553(0.073)$ & $-0.895(0.118)$ & $0.173(0.110)$ \\
\hline & $0.611(0.069)$ & $-0.959(0.114)$ & $0.156(0.108)$ \\
\hline \multirow[t]{2}{*}{ Price of Non-Virgin } & $0.268(0.078)$ & $0.151(0.096)$ & $-0.587(0.148)$ \\
\hline & $0.276(0.075)$ & $0.136(0.094)$ & $-0.583(0.147)$ \\
\hline \multirow[t]{2}{*}{ Expenditure } & $1.502(0.091)$ & $0.597(0.113)$ & $0.686(0.115)$ \\
\hline & 1.109 (0.039) & $0.995(0.053)$ & $0.836(0.059)$ \\
\hline
\end{tabular}

Note: Standard errors are in parentheses. The estimates from the AIDS model without addressing the expenditure endogeneity are in Italics. The Hausman test rejects the hypothesis that "the difference in coefficients is not systematic" for both methods of product classifications at the five percent confidence level. Price elasticities are compensated elasticities based on expenditure shares in the conditional demand system. All elasticities are evaluated at the market shares over the period January 2010 to December 2012. 
We first discuss the price elasticities of demand in Table $2 .{ }^{22}$ We find that the price elasticity of demand for EU virgin oils is -0.436. The U.S. demand for non-EU virgin olive oil is estimated to be price-elastic, with the own price elasticity above one. The own price elasticity of demand for non-virgin oil is about -0.67 . We also find that different types of olive oils are highly substitutable, which helps explain the relatively elastic demand we find for each individual product.

The price elasticities of demand under the alternative product classification are qualitatively similar. The main difference lies in demand for Italian virgin oils. Once we separate other EU countries from Italy and shift their virgin oils to the "Non-Italy/Virgin" category, the own price elasticity for Italian virgin oils is -0.82, almost doubling that for EU virgin oils. This result can be explained by the fact that the olive sectors in Italy, Spain, and Greece compete for the U.S. market. Therefore, price changes in Italian virgin oils alone would induce consumers to switch to the Spanish or Greek substitutes.

Furthermore, we affirm that it is helpful to deal with the endogeneity of the expenditure variable in the demand system. The Hausman test results reject the hypothesis that the expenditure variable is exogenous, suggesting that the U.S. total expenditure on olive oils is simultaneously determined with demand for individual olive oil products. We discuss expenditure responses below where full income effects are reported. In addition, we find from the estimated coefficients for the monthly dummies (omitted from the table for brevity) that there is no significant seasonal variation in the importing of olive oils, but the shares of virgin oils are slightly larger in summer months. One possible explanation is that more olive oils are used as salad dressings in summer time.

Consider next the expenditure equation (2) and factors driving the U.S. total expenditure on olive oils. Note that the two methods of product classification share the same specification of (2)

\footnotetext{
${ }^{22}$ Price elasticities are computed as the compensated price elasticities as in Chalfant (1987). Alston, Foster, and Green (1994) show that formulas in Chalfant (1987) are reasonable approximations for the exact elasticities derived from the AIDS model using the original price index.
} 
except for the corrected Stone price index. As shown in Table 3, the estimates under both product classifications are very similar. Therefore, we base our discussions on the results under the first product classification.

Table 3. The U.S. expenditure on olive oil

\section{Dependent variable: log of U.S. per-capita expenditure on olive oils}

\section{Independent variables:}

Corrected Stone price index

$\frac{\text { Production classification I }}{0.743(0.054)} \quad \frac{\text { Product classification II }}{0.773(0.054)}$

Log of per-capita income

$0.902(0.363)$

$1.215(0.359)$

Log of CPI

$-0.738(0.367)$

$-1.073(0.364)$

Log of canola oil price

$0.093(0.046)$

$0.084(0.046)$

Log of \# of accumulated articles,

$0.178(0.035)$

$0.150(0.035)$

up to 12 months ago

Log of \# of articles,

$0.034(0.035)$

$0.031(0.035)$

in the past 12 months

Log of per-capita cheese import $\quad 0.084(0.024)$

$0.087(0.024)$

Constant

$0.052(1.035)$

$-0.778(1.026)$

$\mathrm{R}^{2}$

0.88

0.88

Note: Standard errors are in parentheses.

We compute the price elasticity of U.S. demand for all olive oils using the estimated coefficient for the corrected Stone price index in Table 3. Specifically, if we aggregate all olive oils into a single product using the Divisia volume index, the corresponding price elasticity of demand for olive oil is $-0.257(=0.743-1) .{ }^{23}$ Note that the demand for olive oil, as a single product, is less elastic than the demand for individual olive oil products because of the substitution within olive oil varieties. To put the magnitude of the price response in perspective, Yen, Kan, and Su (2002) report

\footnotetext{
${ }^{23}$ The U.S. expenditure on olive oil can be characterized by the product of the Stone price index and the Divisia volume index.
} 
that the price elasticity of demand for cooking oil in the United States is about -0.5. Therefore, the U.S. demand for olive oil, as a single product, is less sensitive to price changes than major vegetable oils.

We use the estimates in Table 3 along with the expenditure elasticities in Table 2 to calculate other elasticities of the U.S. demand for olive oils as reported in Table 4. Specifically, the elasticities in Table 4 are the product of the expenditure elasticities in Table 2 and the estimated coefficients for the variables of interest in Table 3. We find that each type of olive oil is a normal good, with the income elasticities positive and statistically significant (except for non-EU virgin oils). In particular, the income elasticities for EU virgin oils is estimated to be above one, and the income effect is even larger for virgin olive oil imported from Italy. These results are consistent with the fact that olive oil is a specialty food item and that the high-end segment of the market has luxury features. 
Table 4. Other elasticities of U.S. demand for olive oils

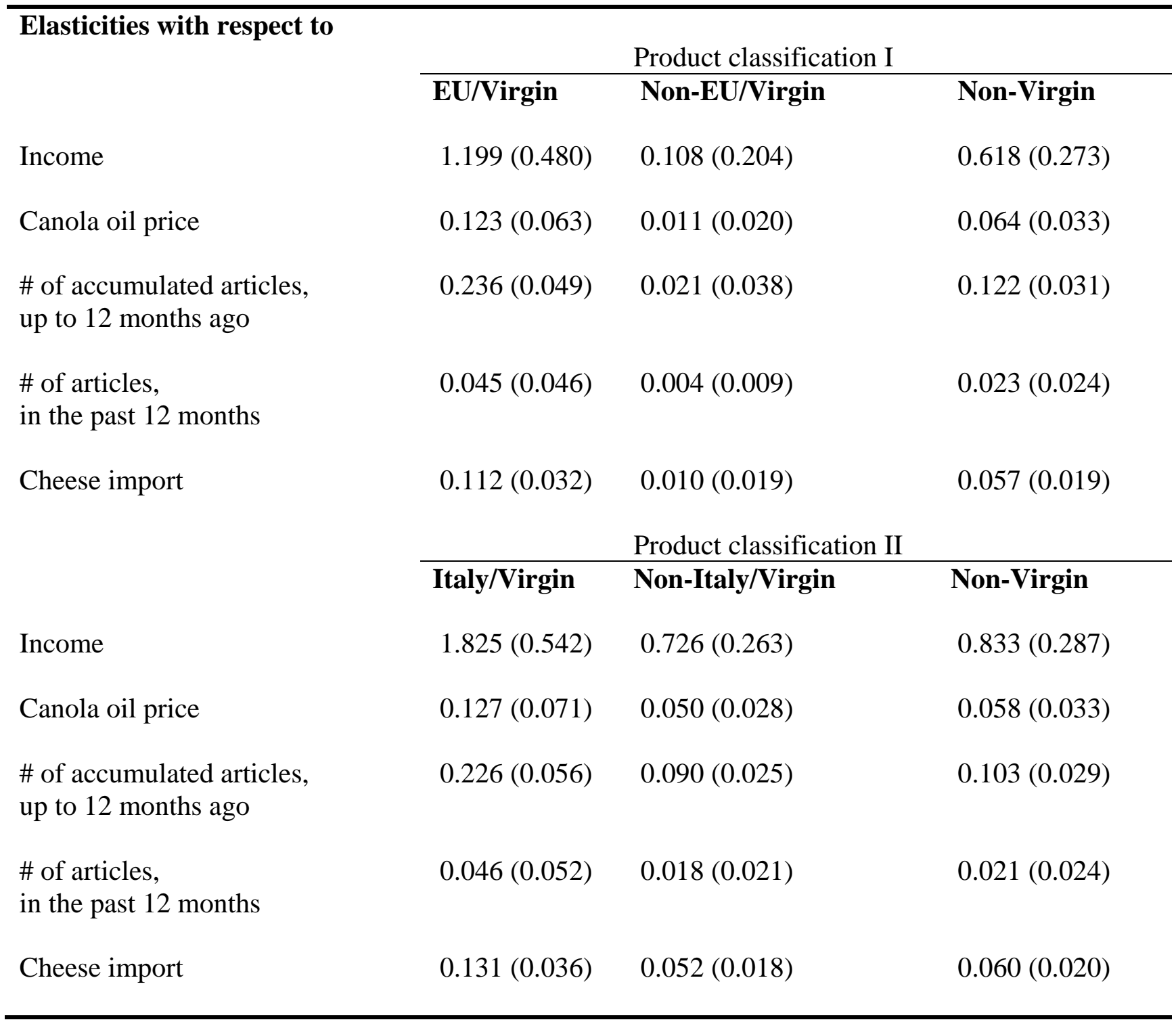

Note: The elasticities are nonlinear functions of the estimated coefficients in the demand system. The associated standard errors are calculated using the Delta method. 
We also find in Table 4 that canola oil substitutes with olive oil, but the effect is marginally significant. The magnitude of the cross-price elasticity is below 0.13 for any olive oil variety under either product classification. In comparison, the cross-price elasticity within different types of olive oils ranges from 0.15 to 1 (see off-diagonals of Table 2). This finding is consistent with our observation that olive oil is a specialty vegetable oil and it has no close substitutes among ordinary vegetable oils (recall Figure 1).

Importantly, we find that news articles about the healthiness or culinary benefits of olive oil contribute significantly to U.S. rising demand for olive oils. Furthermore, the publications stimulate more demand for olive oil mainly through cultivating consumers' awareness of the good attributes of olive oil over an extended period of time. More recent publications, however, do not significantly affect the olive oil market in the United States. We also find that the news reports promote the U.S. demand for EU virgin oils more than that for other oils. Given the stock of articles and the value of U.S. import of olive oils as of 2012, 100 more articles on the health or culinary benefits of olive oil would increase the value of U.S. annual import of olive oils by about \$1.6 million in the long run.

Finally, we find that Americans' growing appetite for the Mediterranean diet more generally has driven part of the expansion of U.S. olive oil demand. Variations in U.S. import of Italian-style cheeses, which we use as a proxy for widening acceptance of Mediterranean foods, significantly affect the U.S. import of olive oils.

\subsection{The sensitivity analysis}

The assumption that the expenditure on the foods of interest is separable from the overall consumer budget is a longstanding caveat in the food demand literature. The assumption facilitates the derivation of a demand system, at the expense of restricting substitution patterns between foods inside and outside of the group of interest (Moschini, Moro, and Green, 1994). To investigate how 
the demand estimates would vary had the separability assumption not hold, we also fit an incomplete demand system (LaFrance and Hanemann, 1989). Specifically, we explain the U.S. consumption of olive oil is by the prices of olive oil, personal income, and other shifters.

Furthermore, we impose Marshallian symmetry by restricting parameters and homogeneity by deflating all nominal variables by CPIs. ${ }^{24}$

The results from the incomplete demand system suggest that the income effects are robust to the choice of demand system. In particular, all olive oils have positive income elasticities and EU virgin olive oils have income elasticities above one. The own-price elasticities of demand for individual types of olive oils are estimated to be around -0.3 , which is the price elasticity of demand for all olive oils in the complete demand system. This result follows because some types of olive oils are found to be complements (although statistically insignificant) under the incomplete demand system. Therefore, the price elasticities for individual products are not significantly larger than the price elasticity for olive oil as a single product.

The impacts of demand shifters are largely consistent with the results from the complete demand systems. In particular, we confirm that the expansion of the U.S. market for olive oil is attributable to the rising awareness of the healthiness and culinary benefits of olive oils and the spread of the Mediterranean diet in general. Further, we find that news articles on the healthiness or culinary benefits of olive oil promote the demand for olive oils primarily in the market for virgin oils. Nevertheless, we find that canola oil substitutes with virgin olive oils but complements to nonvirgin olive oils in the incomplete demand system. Recent articles about the good attributes of olive oil inversely affect the imports of olive oils, but the impact is barely statistically significant.

\section{Conclusions}

\footnotetext{
${ }^{24}$ We use the Marshallian symmetry to approximate the Hicksian symmetry because the changes in olive oil prices have negligible impacts on U.S. personal income due to the tiny expenditure share of olive oil.
} 
The market for olive oil in the United States has tripled over the past two decades. The new market opportunity and related quality issues have provoked increased interest in olive oil production and policy debate in the United States.

In this article, we contribute to the better understanding of the U.S. olive oil market by investigating key determinants of the demand for olive oils. Using data from U.S. customs, we find that the demand for all olive oil is inelastic in the United States (with an own price elasticity around -0.3). However, olive oils of different characteristics and countries of export are highly substitutable and the own price elasticity for each category of olive oil ranges from -0.4 to -1.4 . We also show that virgin olive oil imported from EU has an income elasticity above one. Furthermore, we find that olive oil barely substitutes with ordinary vegetable oils including canola oil.

Importantly, we find that news reports on the healthiness or culinary benefits of olive oil and Americans’ growing appetite for a Mediterranean diet contribute to the growth of the olive oil market in the United States. These results illustrate that healthiness and related food attributes are important drivers of the dietary changes in the United States. Our results have laid foundations for future investigations of the emerging olive oil markets outside of the Mediterranean region. These results illustrate that healthiness and related food attributes are important drivers of the dietary changes in the United States. Food demand studies must increasingly incorporate information about consumer health interests and culinary trends. These shifts may create new opportunities or challenges for exporters from the developing world (Unnevehr, 2000).

Accurate estimates of demand parameters are critical to measuring and projecting impacts of domestic and trade policy options. This article provides the first econometric estimates for olive oil in the United States. Combining the current results with supply side information, future research 
can begin to assess implications of potential U.S. trade policy or quality regulations in the olive oil market.

In addition, olives and olive oil can be important contributors to economic development of agriculture in the rural areas of the Middle East and North Africa. We show that olive oil shipped directly from these countries has grown, but still trades at a price discount. We show that olive oil generally and virgin oil specifically has gained from media attention and this attention could be used to benefit high-quality exporters from developing countries. Improving quality and reputation in the new consumption markets could increase the returns to olive farms, oil processors, and trading firms. 


\section{References}

Alston, J. M., Foster, K. A., and Green, R. D. (1994). Estimating elasticities with the linear approximate almost ideal demand system: some Monte Carlo results. The Review of Economics and Statistics, 351-356.

Brown, D. J., \& Schrader, L. F. (1990). Cholesterol information and shell egg consumption. American Journal of Agricultural Economics, 72(3), 548-555.

Butler, J. (2012). European Commission asked to act on threat of U.S. 'trade barriers.' The Olive Oil Times. http://www.oliveoiltimes.com/olive-oil-business/europe/european-commissionasked-to-act/30322, November 2, 2012.

Chalfant, J. A. (1987). A globally flexible, almost ideal demand system. Journal of Business and Economic Statistics, 5(2), 233-242.

Chern, W. S., Loehman, E. T., and Yen, S. T. (1995). Information, health risk beliefs, and the demand for fats and oils. The Review of Economics and Statistics, 555-564.

Deaton, A., and Muellbauer, J. (1980). Economics and consumer behavior. Cambridge university press.

Dhar, T., Chavas, J. P., and Gould, B. W. (2003). An empirical assessment of endogeneity issues in demand analysis for differentiated products. American Journal of Agricultural Economics, 85(3), 605-617.

Elliott, G., Rothenberg, T. J., and Stock, J. H. (1996). Efficient Tests for an Autoregressive Unit Root. Econometrica, 64(4), 813-836.

Estruch, Ramón, Emilio Ros, Jordi Salas-Salvadó, Maria-Isabel Covas, Dolores Corella, Fernando Arós, Enrique Gómez-Gracia et al. (2013). Primary prevention of cardiovascular disease with a Mediterranean diet. New England Journal of Medicine. 
Hovhannisyan, V., \& Gould, B. W. (2011). Quantifying the structure of food demand in China: An econometric approach. Agricultural Economics, 42(s1), 1-18.

International Olive Council. (2011). Trade standard applying to olive oils and olive-pomace oils. COI/T.15/NC No 3/Rev. 6, November 2011.

Kaabia, M. B., Angulo, A. M., and Gil, J. M. (2001). Health information and the demand for meat in Spain. European Review of Agricultural Economics, 28(4), 499-517.

Kinnucan, H. W., Xiao, H., Hsia, C. J., \& Jackson, J. D. (1997). Effects of health information and generic advertising on US meat demand. American Journal of Agricultural Economics, 79(1), 13-23.

Kolata, G. (2013). Mediterranean diet shown to ward off heart attack and stroke. The New York Times. http://www.nytimes.com/2013/02/26/health/mediterranean-diet-can-cut-heartdisease-study-finds.html?pagewanted=alland_r=0 , February 26, 2013.

LaFrance, J. T. (1991). When Is Expenditure" Exogenous" in Separable Demand Models? Western Journal of Agricultural Economics, 49-62.

LaFrance, J. T., and Hanemann, W. M. (1989). The dual structure of incomplete demand systems. American Journal of Agricultural Economics, 71(2), 262-274.

Martinez, S. (2013). Introduction of New Food Products with Voluntary Health-and NutritionRelated Claims, 1989-2010. USDA-ERS Economic Information Bulletin, (108).

Mili, S. (1996). Organización de mercados y estrategias empresariales en el subsector del aceite de oliva. Ministry of Agriculture, Fisheries and Food, Publishing Services, Madrid, p. 219-232. Menapace, L., Colson, G., Grebitus, C., and Facendola, M. (2011). Consumers’ preferences for geographical origin labels: evidence from the Canadian olive oil market. European Review of Agricultural Economics, 38(2), 193-212. 
Moschini, G. (1995). Units of measurement and the Stone index in demand system estimation. American Journal of Agricultural Economics, 77(1), 63-68.

Moschini, G., Moro, D., and Green, R. D. (1994). Maintaining and testing separability in demand systems. American Journal of Agricultural Economics, 76(1), 61-73.

Okrent, A. M., and Alston, J. M. (2011). Demand for Food in the United States. Monograph 48 The Giannini Foundation, University of California.

Owen, R. W., Giacosa, A., Hull, W. E., Haubner, R., Würtele, G., Spiegelhalder, B., and Bartsch, H. (2000). Olive-oil consumption and health: the possible role of antioxidants. The Lancet oncology, 1(2), 107-112.

Pierani, P., and Rizzi, P. L. (1991). An econometric analysis of the olive oil market in Italy. European Review of Agricultural Economics, 18(1), 37-60.

Sofi, F, Cesari, F., Abbate, R., Gensini, G.F., Casini, A. (2008). Adherence to Mediterranean diet and health status: meta-analysis. British Medical Journal, 337: a1344.

The Economist. (2012). Drizzle and drought. http://www.economist.com/node/21563304, September 22, 2012.

Thompson, W. (2004). Using elasticities from an almost ideal demand system? Watch out for group expenditure! American Journal of Agricultural Economics, 86(4), 1108-1116.

Tuck, K. L., and Hayball, P. J. (2002). Major phenolic compounds in olive oil: metabolism and health effects. The Journal of Nutritional Biochemistry, 13(11), 636-644.

United States Department of Agriculture- Foreign Agricultural Service. Data file “Oliseeds” in the Downloadable Data sets, PSD Online. http://www.fas.usda.gov/psdonline/psdDownload.aspx 
United States Department of Agriculture- Agricultural Marketing Service. United States standards for grades of olive oil and olive-pomace oil. http://www.ams.usda.gov/AMSv1.0/getfile?dDocName=STELDEV3011889

United States International Trade Commission. (2012). Olive oil will be focus of new USITC study. http://www.usitc.gov/press_room/news_release/2012/er1001kk1.htm, October 1, 2012.

Unnevehr, L. J. (2000). Food safety issues and fresh food product exports from LDCs. Agricultural Economics, 23(3), 231-240.

Yen, S. T., Kan, K., and Su, S. J. (2002). Household demand for fats and oils: two-step estimation of a censored demand system. Applied Economics, 34(14), 1799-1806. 


\section{Appendix A}

Table A. Data series and sources

\begin{tabular}{|c|c|}
\hline Series & Source \\
\hline U.S. import quantity of olive oils & U.S. Customs \& Border Protection \\
\hline U.S. import value of olive oils & U.S. Customs \& Border Protection \\
\hline U.S. import quantity of Italian-style cheese & U.S. Customs \& Border Protection \\
\hline $\begin{array}{l}\text { U.S. import price of canola oil, computed as } \\
\text { import value divided by import quantity }\end{array}$ & U.S. Customs \& Border Protection \\
\hline U.S. quarterly personal income & $\begin{array}{l}\text { U.S. Bureau of Economic Analysis } \\
\text { http://www.bea.gov/iTable/index_nipa.cfm }\end{array}$ \\
\hline U.S. monthly population estimate & $\begin{array}{l}\text { U.S. Census Bureau } \\
\text { http://www.census.gov/popest/data/index.html }\end{array}$ \\
\hline $\begin{array}{l}\text { U.S. monthly Consumer Price Index, } \\
\text { city averages for all urban consumers }\end{array}$ & $\begin{array}{l}\text { U.S. Bureau of Labor Statistics } \\
\text { http://www.bls.gov/cpi/\#data }\end{array}$ \\
\hline $\begin{array}{l}\text { News articles on the health or culinary } \\
\text { benefits of olive oil }\end{array}$ & $\begin{array}{l}\text { News Bank } \\
\text { http://www.newsbank.com/ }\end{array}$ \\
\hline
\end{tabular}

Note: U.S. Customs \& Border Protection data is available from USITC Interactive Tariff and Trade DataWeb at http://dataweb.usitc.gov/scripts/user_set.asp. The product codes for olive oil imports in the USITC database are: 1509102000, 1509104000, 1509902000, and 1509904000. U.S. quarterly personal income is transformed to monthly series using the method of the Federal Reserve Bank of St. Louis. http://research.stlouisfed.org/fred2/series/POP?rid=59andsoid=19 


\section{Appendix B}

Table B. The statistical tests for unit roots and first-order serial correlations GLS modified Dickey-Fuller test $^{\mathrm{a}}$

Null hypothesis

Tau statistic ${ }^{\mathrm{b}}$

Expenditure share of EU/Virgin contains unit root

$-5.17$

Expenditure share of Non-EU/Virgin contains unit root

$-6.12$

Expenditure share of Italy/Virgin contains unit root

$-5.59$

Expenditure share of Non-Italy/Virgin contains unit root

$-6.50$

Expenditure share of Non-Virgin contains unit root

$-5.62$

Log of per-capita expenditure on olive oil contains unit root

$-3.71$

\section{Durbin-Watson d-statistic ${ }^{c}$}

Expenditure share of EU/Virgin

d statistic ${ }^{d}$

Expenditure share of Non-EU/Virgin

1.79

Expenditure share of Italy/Virgin

1.97

Expenditure share of Non-Italy/Virgin

2.06

Expenditure share of Non-Virgin

1.98

Log of per-capita expenditure on olive oil

Note: a. All regression equations for the unit-root test contain a deterministic trend and two lagged variables at maximum. b. The interpolated critical value with two lagged variables from Elliott, Rothenberg, and Stock (1996) is -2.90 at the $5 \%$ significance level. c. The right hand side of the auxiliary regressions includes all exogenous variables. $d$. The corresponding lower and upper critical values for the positive autocorrelation test are 1.64 and 1.96 respectively at the $5 \%$ significance level. 


\section{Appendix C}

Table C. Hausman-Durbin-Wu tests for U.S. import prices of olive oils

Regression equation $\quad$ Per-capita quantity of each olive oil product is explained by the own price, per-capita income, canola oil price, CPI, two article indices, percapita cheese import, and monthly dummies.

\section{Instrumental} variables

Annual dummy variables based on marketing years (as proxies for olive yields in the Mediterranean region); a linear time trend (to control for the decline of trans-Atlantic transportation cost)

Null hypothesis

"Import price of the following product is exogenous to its import quantity"

\begin{tabular}{lccccc}
\hline Test result & EU/Virgin & Non-EU/Virgin & Italy/Virgin & Non-Italy/Virgin & Non-Virgin \\
First-stage $\mathrm{R}^{2}$ & 0.66 & 0.56 & 0.68 & 0.59 & 0.57 \\
P-value & 0.16 & 0.08 & 0.34 & 0.57 & 0.04
\end{tabular}

Note: The test is conducted for each olive oil product separately. 


\section{Appendix D}

Table D. Estimated coefficients from the AIDS model with endogenous expenditure The share equations $^{\mathrm{a}, \mathrm{b}}$

Log of price of EU/Virgin

$-0.142(0.045)$

$0.118(0.027)$

$0.024(0.039)$

Log of price of Non-EU/Virgin

$0.025(0.018)$

$-0.048(0.016)$

$0.023(0.018)$

Log of price of Non-Virgin

$-0.082(0.038)$

$0.043(0.021)$

$0.039(0.043)$

Log of expenditure

$0.198(0.036) \quad-0.113(0.028)$

$-0.085(0.031)$

Time trend ${ }^{\mathrm{C}}$

$0.006(0.002)$

$0.011(0.001)$

$-0.017(0.002)$

Intercept

$-0.361(0.119)$

$0.385(0.091)$

$0.976(0.103)$

$\mathrm{R}^{2}$

0.99

0.78

n.a.

Product classification II

Italy/Virgin Non-Italy/Virgin Non-Virgin

Log of price of Italy/Virgin

$-0.188(0.044)$

$0.154(0.035)$

$0.034(0.035)$

Log of price of Non-Italy/Virgin

$0.036(0.032) \quad-0.025(0.037)$

$-0.011(0.030)$

Log of price of Non-Virgin

$-0.058(0.035)$

$-0.003(0.032)$

$0.061(0.042)$

Log of expenditure

$0.210(0.038)$

$-0.125(0.035)$

-0.085 (0.031)

Time trend ${ }^{\mathrm{C}}$

0.002 (0.002)

$0.015(0.002)$

$-0.017(0.002)$

Intercept

$-0.474(0.126)$

$0.498(0.116)$

$0.976(0.103)$

$\mathrm{R}^{2}$

0.97

0.94

n.a.

Note: a. Monthly dummy variables are included in the share equations but omitted from the table for brevity. b. The corrected Stone price index is disintegrated and subsumed into the estimates for three price variables. c. A unit increment in the linear time trend represents a year. 